\title{
Social aspects role and the behavior of drinking water among students in a private university
}

\author{
Sitti Nur Djannah, Ratu Matahari
}

Faculty of Public Health, Universitas Ahmad Dahlan, Indonesia

\begin{tabular}{|c|c|}
\hline Article Info & ABSTRACT \\
\hline Article history: & \multirow{9}{*}{$\begin{array}{l}\text { Lack of consuming drink water can cause many effects on the body. } \\
\text { The long term effects of less consuming water dangerous for health. } \\
\text { The diseases related to the less consuming water are respiratory tract } \\
\text { infections, gastrointestinal disease, urinary infections, cancer, diabetic, } \\
\text { kidney disease, and also others metabolic disorders. Those diseases affected } \\
\text { to the financial burden due to this situation. It happens because of some } \\
\text { factors, many studies mentioned about the behavior of drinking water among } \\
\text { adolescents in school affected by some sociodemographic and behavioral } \\
\text { factors. This study shows that most of respondents have a bad habit to keep } \\
\text { their health kidney it is evident that the majority of respondents have urine } \\
\text { color that tends to concentrated which is categorized as unhealthy urine. } \\
\text { The limitation of the study was not measure the amount of drink water } \\
\text { consuming for each respondents per day. }\end{array}$} \\
\hline Received Dec 6, 2019 & \\
\hline Revised Mar 4, 2020 & \\
\hline Accepted Apr 30, 2020 & \\
\hline Keywords: & \\
\hline Drink water behavior & \\
\hline Private university & \\
\hline Social aspects role & \\
\hline University student & \\
\hline
\end{tabular}

This is an open access article under the $\underline{C C B Y-S A}$ license.

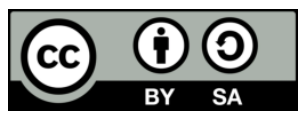

\section{Corresponding Author:}

Ratu Matahari,

Department of Public Health,

Public Health Faculty,

Universitas Ahmad Dahlan,

Jl. Prof. Dr. Soepomo, Janturan Warungboto, Yogyakarta, Indonesia.

Email: ratu.matahari@ikm.uad.ac.id

\section{INTRODUCTION}

The major way to survive from the live on land is water. Our adult body consists of $75 \%$ of water and $55 \%$ in the infant stage; a human can only survive a few days without water [1]. It prevents dehydration [1]. Adolescence as a group of age that experienced with many changing of their life, for instance, the changing of mental, biological, psychological, and also physiological. Those changing influence them about how to react to the situation, high experimentation, exploration, also brave to take a risk. This situation makes adolescent also influenced by their surrounding, including health problem [2]. Healthy behavior among adolescents has been changing. In America, many adolescents often consumes sweet drinks [3-5]. Sweet drinks also very popular in Asia, such as boba drink, milk tea, that contains high sugar on it [6].

Shifting food intake patterns are ones mainly occurs in adolescents, many teenagers who use drinks intake like dangerous drinks like liquor and supplemented drinks, as well drinking less water, so the trend in the intake pattern causes kidney failure young age [7]. Kidney failure disease is a non-communicable disease with a large and suctioning rate of health insurance, Indonesia has a spesific health program to improving healthy behavior among the community members called "Germas" is expected to reduce the incidence of disease kidney failure. The provincial of Yogyakarta mentioned ready to implement "Germas" in 2016 - 2019 with initially three priority programs, namely promoting healthy living such as drinking enough water, 
in addition to two other programs such as increase physical movement and increase consumption of fruits and vegetables [8].

Lack of consuming drink water can cause many effects on the body. Some study mentioned that adolescents prefer to consume sugar drink than drinking water. Adolescents drink soft drink as much as 230 calories per day and also other sweetened drinks in 100 calories per day [9]. Some effects of drinking less than $2 \%$ of body mass water will cause mood swing, exhausted, decreasing of endurance and also awareness $[2,3,10]$. Among students, lack of consuming mineral water drink will affect their concentration [11].

The longterm effects of less consuming mineral water dangerous for health. Dehydration is a manifestation of dying among adolescents. Some diseases also relate to the dehydration such as respiratory tract infections, gastrointestinal disease, urinary infections, cancer, diabetic, kidney disease, and also other metabolic disorders [12]. This situation related to some factors, many studies mentioned the behavior of drinking waterdrinking waterdrinking water among adolescents in school affected by some sociodemographic and behavioral factors $[3,13]$. This study aimed to describe the perception of adolescent about the role of social influence and their behavior of consuming water toward the color of their urine.

\section{RESEARCH METHOD}

This is a cross sectional study to describes the perception of adolescent toward the role of social factors surrounding them [14]. The population of the study was the first semester students of public health faculty in a private university. The students were chosen as the respondents of this study because they get subject about biomedical interm of theory also practical. They are actively chosen to participate in this study. Total sampling was applied in this study. There were 287 university students participated in this study.

The questions were derived from World Health Organization standard questionnaire. The question related to the perception of social role towards drinking water behavior, the habit of the adolescent to drink water towards the color of urine. The conceptual framework of this paper was drawn by the Health Belief Model theory. This theory applied to explain what adolescents think about their social circle to support drinking water and also explain the behavior of the adolescents to consume drinking water to the color of urine, and the behavior of the adolescents to maintain their health kidney towards the color of urine [15].

\section{RESULTS AND DISCUSSION}

Based on the data analysis, we found some situation related to the behavior of the students on drink water in a day. Social environment surrounds the respondents have no correlation to support to keep their healthy kidney by drink water routinely but the behavior of drink water correlate to the habit to drink water and also their urine colour.

\subsection{Sociodemographic of the respondents}

There are 287 respondents who are participated in this study. Majority of the respondents were female $(84 \%)$ and the others $16 \%$ are male. Respondents who have habit of drinking water $\geq$ glasses each day are $24 \%$. Most of the respondents behave to keep their kidney health as many $56 \%$ and $54 \%$ of respondents have the unhydrated urine color. The sociodemographic of the respondents show in Table 1

Table 1. Distribution of frequency of sociodemographic of the respondents

\begin{tabular}{|c|c|c|c|}
\hline \multicolumn{2}{|c|}{ Characteristics of the Respondents } & \multirow{2}{*}{$\frac{\text { Frequency }(\mathrm{n})}{242}$} & \multirow{2}{*}{$\begin{array}{c}\text { Percentage }(\%) \\
84\end{array}$} \\
\hline Sex & Female & & \\
\hline & Male & 45 & 16 \\
\hline \multirow[t]{2}{*}{ Role of father on drinking water } & Risky & 83 & 29 \\
\hline & Not Risky & 204 & 71 \\
\hline \multirow[t]{2}{*}{ Role of mother on drinking water } & Risky & 51 & 18 \\
\hline & Not Risky & 236 & 82 \\
\hline \multirow[t]{2}{*}{ Role of sibling on drinking water } & Risky & 170 & 59 \\
\hline & Not Risky & 117 & 41 \\
\hline \multirow[t]{2}{*}{ Role of friends on drinking water } & Risky & 186 & 65 \\
\hline & Not Risky & 101 & 35 \\
\hline \multirow[t]{2}{*}{ Habit of drinking water } & Risky (<8 glasses/day & 46 & 46 \\
\hline & Not Risky ( $\geq 8$ glasses/day) & 54 & 54 \\
\hline \multirow[t]{2}{*}{ Behaviour to keep kidney health } & Risky & 126 & 44 \\
\hline & Not Risky & 161 & 56 \\
\hline \multirow[t]{2}{*}{ The Color of Urine } & Unhydrated well & 155 & 54 \\
\hline & Hydrated well & 132 & 46 \\
\hline Total & & 287 & 100 \\
\hline
\end{tabular}




\subsection{The perceived of social environmental's role surround the respondents}

Table 2 shows that most of adolescents $(83.2 \%)$ perceived that their mother has an excellent role in encouraging them to drink water. As many as 200 (71.8\%) adolescents mentioned that they have a good perception that their fathers encourage them to drink water. Most of the adolescents perceived that siblings $(57.6 \%)$ and friends $(64.4 \%)$ have a bad encourage to drink water.

Social factors have the impact of adolescents' behavior to imply some activities. The social aspects describe that the acceptance of individual to do an activity which means the behavior of consuming drink water because they have a similarity about the impact or benefit they will get [16]. The adolescents built the perception that parents strongly encourage them to drink water. Parents as the role model at home have a strong influenceon their children. A study mentioned that parents become a usual barrier in terms of limiting the sweetened water of other sweet meals because of lack of role modeling. Children will see and copy what parents did surround them (in terms of eating and drinking behaviors, lifestyle, and attitude that construct the norm of a family [17, 18]. This study found interesting points; adolescents have some inclusive characteristics that are changing in biological, physiological, psychological. Most of the adolescents characterized feel intimate with their friends or peer $[13,19]$. It assumes that adolescents in this study have a strong social norm in their family [16].

Table 2. The perceived of social environtment's role surround the respondents

\begin{tabular}{lccc}
\hline Variables & Category & $\mathrm{n}=287$ & $\%$ \\
\hline \multirow{2}{*}{ The role of mother towards the behavior of drink water among adolescents } & Bad & 52 & 16.8 \\
& Good & 235 & 83.2 \\
The role of father towards the behavior of drink water among adolescents & Bad & 87 & 28.2 \\
& Good & 200 & 71.8 \\
The role of siblings towards the behavior of drink water among adolescents & Bad & 178 & 57.6 \\
& Good & 109 & 42.4 \\
The role of friends towards the behavior of drink water among adolescents & Bad & 199 & 64.4 \\
& Good & 88 & 35.6 \\
\hline
\end{tabular}

\subsection{The correlation between behavior to maintain helth kidney towards habits of drink water}

Most of the adolescents $(66.1 \%)$ who have a good habit on consume drink water will have good health kidney, compared with the adolescents who have poor behavior in maintaining poor kidney health which is equal to $40 \%$. While respondents who are not good habits in consuming water is more influenced by the behavior of respondents who are not good in maintaining kidney health, which is equal to $60 \%$. Chi-square test obtained $p$ value of 0.000 . Based on this result, it can be concluded that there is a significant correlation between the behaviors of maintaining kidney health with the habits of respondents consuming water; illustrated in the Table 3.

Table 3. The correlation between behaviors to keep health kidney towards habits of drink water

\begin{tabular}{ccccccc}
\hline \multirow{2}{*}{ Behaviour to Keep } & \multicolumn{4}{c}{ Habit of Drink Water } & \multicolumn{2}{c}{ Total } \\
Health Kidney & $\mathrm{Bad}(<8$ glasses/day $)$ & \multicolumn{2}{c}{ Good $(\geq 8$ glasses/day $)$} & $\mathrm{N}$ & $\%$ \\
\hline Bad & 81 & 60.0 & Bad & 81 & 60.0 & Bad \\
Good & 59 & 33.9 & Good & 59 & 33.9 & Good \\
\hline $\mathrm{p}=0.000$ & & & & & &
\end{tabular}

The findings of the present study show that the adolescents who are highly aware of their kidney health have a good habit of consuming drink water regularly as a minimum eight glass per day [11]. It should be noted that the health kidney also has a correlation to the kind of activities of the respondents. It is important to understand the activities of respondents per day and the amount of water consumed [20]. The kind of drinking water is also apart of behavior to maintain a healthy kidney. A study mentioned that adolescents in Latin America prefer to consume sweetened soft drink [21], but adolescents in Asia especially in China and Indonesia most likely to drink milk, tea, and coffee that ready to drink [17, 21, 22]. The school or university should have the regulation on drinking. This situation should become concerned related maintain the health kidney towards improving the habits of drink water among students [13, 19, 23, 24].

\subsection{The correlation between behavior to keep the hydrated colour of urine}

The percentage of respondents who have good (clear) urine color is caused by the behavior of maintaining good kidney health by respondents which is $51.7 \%$, compared to the bad behavior in maintaining 
kidney health that is equal to $39.3 \%$. While urine color that is not good (concentrate) is greater due to the behavior of maintaining kidney health which is also categorized as not good at $60.7 \%$ compared to the behavior of maintaining good kidney health at $48.3 \%$. The Chi square obtained p-value of 0.029 which means that there is a significant relationship between the colors of the urine of respondents with the behavior of maintaining kidney health by respondents; presented in the Table 4.

Table 4. The correlation between behaviors to keep the hydrated colour of urine

\begin{tabular}{ccccccc}
\hline $\begin{array}{c}\text { Behaviour to Keep } \\
\text { the Hydrated }\end{array}$ & \multicolumn{3}{c}{ Bad (Concentrated) } & \multicolumn{2}{c}{ Good } & \multicolumn{3}{c}{ Total } \\
Colour of Urine & $\mathrm{N}$ & $\%$ & $\mathrm{~N}$ & $\%$ & $\mathrm{~N}$ & $\%$ \\
\hline Bad (Concentrated) & 82 & 60.7 & 53 & 39.3 & 135 & 100 \\
Good & 62 & 48.3 & 90 & 51.7 & 152 & 100 \\
\hline $\mathrm{p}=0.029$ & & & & &
\end{tabular}

Urine colour is the indicator of the hydrating of body. Water intake is very important to maintain hydration [25]. The current study indicates that respondents should be increasing the total water intake. This situation becomes a public health problem, so it needs the strategies to increase the awareness of the respondent about habit to maintain the health kidney through increasing the behavior of drinking waterdrinking waterdrinking water $[5,13,26]$. The habit of drinking wateris very important to maintain the physiological functions interm of blood pressure, basal temperature, and $\mathrm{pH}$ because water is a supply machine of oxygen, glucose, sodium, and also potassium to the body [9, 27]. The colour of the urine will be the sign that the body needs to be hydrated [28-30].

\section{CONCLUSION}

Based on the results of the study, we conclude that siblings and friends of the respondent have the good role in encouraging respondents to drink water simultaneity per day. Most of the respondents have a bad habit of treating their health kidney. It is evident that the majority of respondents have a urine color that tends to concentrated which is categorized as unhealthy urine. The limitation of the study did not measure the amount of drink water consuming for each respondent per day.

\section{ACKNOWLEDGEMENTS}

Authors would like to thank Universitas Ahmad Dahlan which had fully funded this study and its publication.

\section{REFERENCES}

[1] B. M. Popkin, K. E. D’Anci, and I. H. Rosenberg, "Water, hydration, and health," Nutr. Rev., vol. 68, no. 8, pp. 439-458, 2010.

[2] J. D. Stookey and J. König, "Describing water intake in six countries: results of Liq. In 7 surveys, 2015-2018," Eur. J. Nutr., vol. 57, no. 3, pp. 35-42, 2018.

[3] S. Park, et al., "Factors Associated with Low Drinking Water Intake among Adolescents: The Florida Youth Physical Activity and Nutrition Survey, 2007," J. Am. Diet. Assoc., vol. 111, no. 8, pp. 1211-1217, 2011.

[4] E. L. Kenney, S. L. Gortmaker, J. E. Carter, M. C. W. Howe, J. F. Reiner, and A. L. Cradock, "Grab a cup, fill it up! an intervention to promote the 1 of drinking water and increase student water consumption during school lunch," Am. J. Public Health, vol. 105, no. 9, pp. 1777-1783, 2015.

[5] A. L. Beck, E. M. Iturralde, J. Haya-Fisher, S. Kim, V. Keeton, and A. Fernandez, "Barriers and facilitators to healthy eating among low-income Latino adolescents," Appetite, vol. 138, pp. 215-222, 2019.

[6] X. Zhang et al., "Daily intake of soft drinks is associated with symptoms of anxiety and depression in Chinese adolescents," Public Health Nutr., vol. 22, no. 14, pp. 2553-2560, 2019.

[7] R. K. Dasar, Presentation of Principles of Basic Health Research Results (in Bahasa), 2013.

[8] D. Kuswenda, "Healthy Living Community Movement - Real Action for Healthy Living (in Bahasa)," War. Kesmas, vol. 1, pp. 06-07, 2017.

[9] J. P. Block, M. W. Gillman, S. K. Linakis, and R. E. Goldman, "If it tastes good, i'm drinking it': Qualitative study of beverage consumption among college students," J. Adolesc. Heal., vol. 52, no. 6, pp. 702-706, 2013.

[10] A. Mega Kumala, A. Margawati, and A. Rahadiyanti, "Relationship Between the Duration of Using Electronic Devices (Gadgets), Physical Activity and Diet with Nutritional Status in Adolescents Aged 13-15 years (in Bahasa)," J. Nutr. Coll., vol. 8, no. 2, pp. 73-80, 2019.

[11] E. S. Sudarsono, S. Nurohmi, A. Y. Damayanti, and D. Sari, "Relationship between level of hydration knowledge with total fluid intake on teenage girl (in Bahasa)," Darussalam Nutrition Journal, vol. 3, no. 2, pp. 50-54, 2019.

Social aspects role and the behavior of drinking water among students in a private ... (Sitti Nur Djannah) 
[12] J. Warren, et al., "Challenges in the assessment of total fluid intake in children and adolescents: a discussion paper," Eur. J. Nutr., vol. 57, no. 3, pp. 43-51, 2018.

[13] L. A. Vézina-Im and D. Beaulieu, "Determinants and Interventions to Promote Water Consumption Among Adolescents: A Review of the Recent Literature," Curr. Nutr. Rep., 2019.

[14] C. J. Wright, et al., "How are perceptions associated with water consumption in Canadian Inuit? A cross-sectional survey in Rigolet, Labrador," Sci. Total Environ., vol. 618, pp. 369-378, 2018.

[15] J. Schafer and J. Schafer, "Cornerstone: A Collection of Scholarly and Creative Works for Minnesota State University, Mankato Sugar- Sweetened Beverages: A Survey to Assess Adults Knowledge, Attitudes, and Consumption Patterns of Sugar-Sweetened Beverages," 2019.

[16] J. Previte, M. L. Fry, J. Drennan, and S. F. E. Hasan, "Friends or foes: Group influence effects on moderate drinking behaviors," J. Bus. Res., vol. 68, no. 10, pp. 2146-2154, 2015.

[17] I. Guelinckx, et al., "Intake of water and beverages of children and adolescents in 13 countries," Eur. J. Nutr., vol. 54, pp. 69-79, 2015.

[18] A. R. Keshavarzi, M. Sharifzadeh, A. A. Kamgar Haghighi, S. Amin, S. Keshtkar, and A. Bamdad, "Rural domestic water consumption behavior: A case study in Ramjerd area, Fars province, I.R. Iran,” Water Res., vol. 40, no. 6, pp. 1173-1178, 2006.

[19] S. Attila and B. Çakir, "Energy-drink consumption in college students and associated factors," Nutrition, vol. 27, no. 3, pp. 316-322, 2011.

[20] Rita Halim and M. H. Mardhiyah, "Overview of Fluid Intake and Nutrition Status in Jambi University Medical Students," JMJ, vol. 6, no. 1, pp. 68-75, 2018.

[21] C. Morin, et al., "Fluid intake patterns of children and adolescents: results of six Liq. In 7 national cross-sectional surveys," Eur. J. Nutr., vol. 57, no. 0, pp. 113-123, 2018.

[22] P. W. Laksmi, et al., "Fluid intake of children, adolescents and adults in Indonesia: results of the 2016 Liq. In 7 national cross-sectional survey," Eur. J. Nutr., vol. 57, no. 3, pp. 89-100, 2018.

[23] N. Michels, K. Van den Bussche, J. Vande Walle, and S. De Henauw, "School Policy on Drinking and Toilets: Weaknesses and Relation with Children's Hydration Status," J. Nutr. Educ. Behav., vol. 51, no. 1, pp. 32-40, 2019.

[24] S. Bakri, "Nutrition status, knowledge and adequate of water consumtion for student of senior high school 12 in Banda Aceh," AcTion Aceh Nutr. J., vol. 4, no. 1, p. 22, 2019.

[25] H. G. Suh and S. A. Kavouras, "Water intake and hydration state in children," Eur. J. Nutr., vol. 58, no. 2, pp. 475-496, 2019.

[26] H. M. S. Wasana, G. D. R. K. Perera, P. D. S. Gunawardena, P. S. Fernando, and J. Bandara, "WHO water quality standards Vs Synergic effect(s) of fluoride, heavy metals and hardness in drinking water on kidney tissues," Sci. Rep., vol. 7, pp. 1-6, 2017.

[27] K. M. Eck, et al., "Your body feels better when you drink water': Parent and school-age children's sugar-sweetened beverage cognitions," Nutrients, vol. 10, no. 9, pp. 12-14, 2018.

[28] I. M. Krecar, M. Kolega, and S. F. Kunac, "The Effects of Drinking Water on Attention," Procedia - Soc. Behav. Sci., vol. 159, pp. 577-583, 2014.

[29] J. Zhang, et al., "The amounts and contributions of total drinking fluids and water from food to total water intake of young adults in Baoding, China," Eur. J. Nutr., vol. 58, no. 7, pp. 2669-2677, 2019.

[30] N. A. Khan, et al., "A 4-d Water Intake Intervention Increases Hydration and Cognitive Flexibility among Preadolescent Children," J. Nutr., 2019. 